\title{
EFEKTIVITAS EKSTRAK LAMUN Cymodocea rotundata, Thalassia hemprichii, DAN Enhalus acoroides DARI PERAIRAN JEPARA SEBAGAI ANTIBAKTERI PADA FILLET IKAN NILA (Oreochromis niloticus) SELAMA PENYIMPANAN DINGIN
}

\section{Effects Of Seagrass Extracts Cymodocea rotundata, Thalassia hemprichii, and Enhalus acoroides From Jepara As Antibacterials On Tilapia (Orechromis niloticus) Fillets During Cold Storage}

\author{
Nikolaus Eric Pradana, Fath F. Wardiwira, Luqmanul Hakim, Azizatul Nur Imamah, Winne Istianisa \\ Program Studi Teknologi Hasil Perikanan, Jurusan Perikanan \\ Fakultas Perikanan dan Ilmu Kelautan, Universitas Diponegoro \\ Jl. Prof. Soedarto, SH Tembalang, Semarang \\ Email : epnikolaus@gmail.com, wardiwira2@gmail.com, alhakimluqman@gmail.com, azizatulimamah@gmail.com, \\ winneistianisa@gmail.com
}

Diserahkan tanggal 13 Januari 2018, Diterima tanggal 19 Februari 2018

\begin{abstract}
ABSTRAK
Penanganan fillet ikan nila segar merupakan bagian penting karena dapat mempengaruhi mutu. Ikan nila memiliki pH mendekati netral yang merupakan media untuk pertumbuhan bakteri pembusuk maupun mikroorganisme lain sehingga mudah mengalami pembusukan. Penambahan bahan antibakteri dari jenis lamun diharapkan mampu menambah masa simpan fillet ikan nila. Ketiga jenis lamun, yaitu Cymodocea rotundata, Thalassia hemprichii, dan Enhalus acoroides digunakan pada penelitian pendahuluan, selanjutnya diambil salah satu yang terbaik untuk masuk dipenelitian utama. Lamun dikeringkan dengan cara diangin-anginkan, lamun kering diekstrak dengan etanol 96\% selama 2 x 24 jam dengan perbandingan bahan : pelarut (1 : 5). Ekstrak lamun disaring untuk memisahkan residu dan pelarut, filtrat diuapkan menggunakan rotary evaporator. Fillet ikan nila direndam ekstrak lamun dengan konsentrasi 20\%, 25\%, dan 30\% selama 2 jam, kemudian diuji TPC dan organoleptik. Berdasarkan hasil penelitian pendahuluan didapatkan Enhalus accoroides dengan konsentrasi 25\% merupakan konsentrasi terbaik berdasarkan nilai TPC dan organoleptik. Penelitian selanjutnya adalah menambahkan ekstrak lamun Enhalus acoroides 25\% dan tanpa penambahan ekstrak Enhalus acoroides sebagai control. Fillet dikemas menggunakan plastik seal dan disimpan pada suhu dingin $4^{\circ} \mathrm{C}$ dalam refrigerator dengan lama penyimpanan $0,3,6$, 9, dan 12 hari. Fillet ikan nila yang disimpan pada suhu dingin menunjukkan bahwa perbedaan penambahan lamun dan lama penyimpanan memberikan pengaruh yang nyata terhadap nilai TPC pada hari ke-12 yaitu $1,16 \times 10^{5} \mathrm{CFU} / \mathrm{g}$, nilai TVBN 26,67 mgN/100g, dan nilai $\mathrm{pH}$ sebesar 7,01.
\end{abstract}

Kata kunci: Fillet ikan nila, Enhalus accoroides, , Antibakteri, TPC

\section{ABSTRACT}

Handling fresh tilapia fillets is an important part because it can affect quality. Tilapia has a pH close to neutral which is a medium for the growth of decomposing bacteria and other microorganisms so that it can easily decay. The addition of antibacterial ingredients from seagrass species is expected to increase the shelf life of tilapia fillets. The three types of seagrass, namely Cymodocea rotundata, Thalassia hemprichii, and Enhalus acoroides were used in the preliminary study, then taken one of the best to enter in the main study. Seagrass is dried by aerating, dried seagrass is extracted with 96\% ethanol for $2 x 24$ hours with a ratio of ingredients: solvent (1: 5). Seagrass extract is filtered to separate the residue and solvent, the filtrate is evaporated using a rotary evaporator. Tilapia fillets were soaked with seagrass extract with concentrations of 20\%, 25\%, and 30\% for 2 hours, then tested for TPC and organoleptic. Based on the results of preliminary research, Enhalus accoroides with a concentration of $25 \%$ was the best concentration based on the value of TPC and organoleptic. The next study was to add 25\% seaweed extract Enhalus acoroides and without the addition of Enhalus acoroides extract as a control. Fillets are packaged using a plastic seal and stored at a cool temperature of $4^{\circ} \mathrm{C}$ in a refrigerator with a storage time of $0,3,6,9$, and 12 days. Tilapia fillets stored at cold temperatures showed that the difference in the addition of seagrass and storage time had a significant effect on the value of TPC on day 12, that is $1,16 \times 10^{5} \mathrm{CFU} / \mathrm{g}$, the TVBN value was $26.67 \mathrm{mgN} / 100 \mathrm{~g}$, and the $\mathrm{pH}$ value was 7.01.

Keywords: Tilapia fillets, Enhalus accoroides, Antibacterials, TPC

\section{PENDAHULUAN}

Ikan nila (Oreochromis niloticus) merupakan ikan ekonomis penting sebagai ikan konsumsi. Ikan nila memiliki daging yang tebal sehingga berpotensi untuk dijadikan sebagai komoditas ekspor dalam bentuk fillet. Menurut Kordi (2010), Amerika Serikat merupakan negara pengimpor nila terbesar di dunia. AS mengimpor ikan nila dari 25 negara termasuk Indonesia. Tahun 2006 Indonesia mengekspor 7.392 ton nila ke AS dalam bentuk irisan daging atau fillet beku dan utuh beku. 
Ikan nila digemari karena selain rasanya yang enak, juga memiliki kandungan gizi yang tinggi seperti protein dan asam lemak. Kandungan protein ikan nila sebesar 13,25\%, lemak $0,57 \%$, kadar abu $1,24 \%$ dan kadar air $81,11 \%$ per 100 gram berat ikan (Olopade et al., 2016).

Penanganan pada fillet ikan nila segar merupakan bagian penting karena dapat mempengaruhi mutu. Hal ini perlu diperhatikan karena ikan nila memiliki $\mathrm{pH}$ mendekati netral sehingga merupakan media yang baik untuk pertumbuhan bakteri pembusuk maupun mikroorganisme lain sehingga ikan nila merupakan bahan pangan yang mudah busuk. Perlu upaya untuk mengawetkan fillet nila sehingga dapat menambah umur simpan dan diterima konsumen dalam keadaan yang masih layak dikonsumsi. Penambahan bahan pengawet alami salah satunya adalah antibakteri dari ekstrak lamun Cymodocea rotundata, Thalassia hemprichii, dan Enhalus acoroides.

Lamun yang terdapat di daerah tropis seperti di perairan Pantai Jepara mendapatkan paparan sinar ultra violet (UV) yang kuat sepanjang tahun dan diduga memproduksi metabolit sekunder untuk mempertahankan hidupnya dari radiasi sinar UV yang dapat memicu terjadinya oksidasi. Senyawa metabolit sekunder pada tumbuhan seperti flavonoid, tanin dan alkaloid berdasarkan beberapa hasil penelitian mempunyai kemampuan untuk menghambat pertumbuhan bakteri, di dalam lamun mengandung senyawa metabolit sekunder yaitu flavonoid dan alkaloid sehingga senyawa aktif tersebut dapat digunakan sebagai antibakteri. Menurut Ravikumar et al. (2008) senyawa bioaktif pada lamun yaitu senyawa alkaloid, flavonoid, dan triterpenoid yang dapat bersifat sebagai antibakteri, dimana senyawa ini mampu menghambat atau mematikan organisme lain. Darwis (2001) menyatakan bahwa alkaloid adalah golongan senyawa basa bernitrogen yang kebanyakan heterosiklik yang banyak terdapat pada tumbuhan, termasuk lamun. Tujuan penelitian ini adalah untuk mengetahui aktivitas antibakteri dan senyawa aktif yang terkandung pada lamun Cymodocea rotundata, Thalassia hemprichii, dan Enhalus acoroides, serta untuk mengetahui pengaruhnya sebagai antibakteri pada fillet ikan nila selama penyimpanan dingin

\section{METODE PENELITIAN}

Penelitian ini dilakukan selama 4 bulan, diawali dengan penelitian pendahuluan dan dilanjutkan penelitian utama. Penelitian pendahuluan difokuskan pada pengujian kandungan senyawa bioaktif ketiga jenis lamun secara kualitatif dan penentuan ekstrak lamun dengan konsentrasi dan jenis lamun terbaik berdasarkan hasil uji terhadap bakteri $S$. aureus (gram positif) dan E. coli (gram negatif) serta uji organoleptik. Penelitian utama merupakan pengembangan dari penelitian pendahuluan dilanjutkan dengan uji TPC, TVBN dan $\mathrm{pH}$ selama penyimpanan dingin (hari ke-0, 3, 6, 9, dan 12).

\section{Penelitian Pendahuluan}

Sampel lamun Cymodocea rotundata, Thalassia hemprichii, dan Enhalus accoroides segar dimasukkan ke dalam kantong plastik polybag, kemudian dibawa menggunakan box styrofoam dari Perairan Teluk Awur, Kabupaten Jepara, Provinsi Jawa Tengah. Sampel ikan nila segar diperoleh dari pembudidaya yang ada di Kecamatan Ungaran, Kabupaten Semarang, Provinsi Jawa Tengah. Pembuatan ekstrak lamun mengacu pada Astuti (2014) yang sudah dimodifikasi, masing-masing serbuk ketiga jenis lamun diekstraksi dengan metode maserasi menggunakan pelarut etanol 96\% (polar) selama $2 \times 24$ jam dengan perbandingan bahan : pelarut adalah 1 : 5 . Setelah itu untuk menguapkan pelarutnya dengan cara evaporasi menggunakan alat rotary evaporator dengan suhu $40^{\circ} \mathrm{C}( \pm 1 \mathrm{jam})$.

Ekstrak ketiga jenis lamun diuji fitokimia secara kualitatif, pengujian mengacu pada Noer dan Rosa (2016), yang meliputi:

\section{a. Uji Alkaloid}

Sebanyak $0,5 \mathrm{~g}$ fraksi aktif ditambah $5 \mathrm{ml}$ asam klorida 10 $\%$, dikocok, dan ditambah $5 \mathrm{ml}$ larutan amoniak $10 \%$. Diekstraksi dengan kloroform dan diuapkan. Residu sisa penguapan ditambah $1,5 \mathrm{ml}$ asam klorida $2 \%$ dan dibagi dalam dua tabung. Tabung pertama ditambahkan 2-3 tetes pereaksi Mayer, Jika terbentuk endapan putih kekuningan menunjukkan adanya alkaloid.Tabung kedua ditambah 2-3 tetes pereaksi Dragendorff, jika terbentuk endapan merah bata menunjukkan adanya alkaloid.

\section{b. Uji Triterpenoid}

Ekstrak etil asetat dimaserasi dengan beberapa $\mathrm{mL}$ eter lalu dipindahkan ke dalam dropple plate untuk diuji dengan pereaksi Liebermann Bouchard (2 tetes asam asetat anhidrat dan 1 tetes asam sulfat pekat). Residu yang tidak larut dalam eter selanjutnya dihidrolisis dengan $\mathrm{HCl} 2 \mathrm{~N}$ di atas penangas air kemudian dilarutkan dalam eter dan diuji kembali dengan pereaksi Liebermann Bouchard. Terbentuknya warna biru atau hijau menunjukkan adanya steroid dan warna merah adanya terpenoid.

c. Uji Flavonoid

Sebanyak 0,5 g fraksi aktif dilarutkan dalam $10 \mathrm{ml}$ air dan dipanaskan diatas penangas air kemudian tambahkan lebih kurang $100 \mathrm{mg}$ serbuk magnesium dimasukkan kedalam tabung pertama lalu ditambah $1 \mathrm{ml}$ asam klorida pekat dan $3 \mathrm{ml}$ amil alkohol, dikocok kuat dan dibiarkan memisah. Warna merah, kuning, jingga pada lapisan amil alkohol menunjukkan adanya flavonoid.

Konsentrasi terbaik ditentukan berdasarkan hasil uji TPC dan uji organoleptik. Sampel fillet ikan nila direndam ekstrak lamun dengan konsentrasi 20\%, 25\%, dan 30\% selama 2 jam lalu diuji TPC (SNI 01-2332.3-2006) dan organoleptik (SNI 2346.2006).

\section{Penelitian Utama}

Sampel direndam ekstrak lamun dengan konsentrasi dan jenis lamun terbaik berdasarkan penelitian pendahuluan. Setelah itu, dikemas menggunakan plastik seal dan disimpan pada suhu dingin $4^{\circ} \mathrm{C}$ dalam refrigerator dengan lama penyimpanan $0,3,6,9$, dan 12 hari. Metode yang digunakan dalam penelitian ini adalah metode experimental laboratories. Pengujian normalitas dan homogenitas dilakukan terlebih dahulu sebelum analisa ANOVA, agar dapat diketahui sifat data sehingga dapat dilakukan sidik ragam atau tidak (Kusriningrum, 2008). Selanjutnya dianalisa dengan sidik ragam atau analysis of varian (ANOVA).

Pegujian yang dilakukan adalah pengujian Total Volatile Base Nitrogen (TVBN) dilakukan di Laboratorium Terpadu Universitas Dipoengoro. Perendaman fillet nila dalam ekstrak lamun, uji Organoleptik, uji Total Plate Count (TPC) dan uji pH dilakukan di Laboratorium Mikrobiologi Teknologi Hasil Perikanan, Fakultas Perikanan dan Ilmu Kelautan, Universitas Diponegoro.

(ㄷ) Copyright by Saintek Perikanan (Indonesian Journal of Fisheries Science and Technology), ISSN : 1858-4748 


\section{HASIL DAN PEMBAHASAN}

Kandungan fitokimia ekstrak Cymodocea rotundata, Thalassia hemprichii dan Enhalus acoroides secara kualitatif menunjukkan respon positif terhadap keberadaan flavonoid, alkaloid dan triterpenoid (Tabel 1). Hal ini ditandai dengan terbentuknya warna merah pada uji flavonoid, endapan merah bata pada uji alkaloid dan warna biru kehijauan pada uji triterpenoid. Rumagit et al. (2015), dalam penelitiannya menjelaskan bahwa hasil positif alkaloid ditunjukkan dengan adanya endapan merah. Hasil positif flavonoid mengalami perubahan warna menjadi hitam kemerahan. Hasil positif steroid (triterpenoid) dibuktikan dengan terjadinya perubahan warna larutan menjadi hijau ketika ditambahkan dengan kloroform dan asam sulfat pekat. Dewi et al. (2012), menambahkan bahwa ekstrak Enhalus acoroides dan Thalassia hemprichii menunjukkan adanya kandungan senyawa bioaktif dari jenis flavonoid, alkaloid, dan steroid.

Tabel 1. Kandungan Fitokimia Kualitatif Ekstrak Cymodocea rotundata, Thalassia hemprichii, dan Enhalus acoroides

\begin{tabular}{cccc}
\hline Jenis Lamun & Flavonoid & Alkaloid & Triterpenoid \\
\hline Cymodocea rotundata & + & + & + \\
Thalassia hemprichii & + & + & + \\
Enhalus acoroides & + & + & + \\
\hline
\end{tabular}

Tabel 2. Hasil Uji Zona Hambat Ekstrak Cymodocea rotundata, Thalassia hemprichii dan Enhalus acoroides Terhadap Bakteri E. Coli dan S. Aureus

\begin{tabular}{cccc}
\hline \multirow{2}{*}{ Jenis Lamun } & Konsentrasi & \multicolumn{2}{c}{ Jenis Bakteri } \\
\cline { 2 - 4 } & $(\%)$ & E. coli & S. aureus \\
\hline \multirow{3}{*}{ Thalassia hemprichii } & 20 & $0,40 \pm 0,15^{\mathrm{a}}$ & $0,55 \pm 0,13^{\mathrm{a}}$ \\
& 25 & $0,68 \pm 0,17^{\mathrm{ab}}$ & $0,76 \pm 0,07^{\mathrm{ab}}$ \\
& 30 & $0,81 \pm 0,12^{\mathrm{b}}$ & $0,88 \pm 0,17^{\mathrm{b}}$ \\
\hline \multirow{3}{*}{ Cymodocea rotundata } & 20 & $0,61 \pm 0,07^{\mathrm{a}}$ & $0,71 \pm 0,12^{\mathrm{a}}$ \\
& 25 & $0,83 \pm 0,10^{\mathrm{ab}}$ & $1 \pm 0,22^{\mathrm{a}}$ \\
& 30 & $1,15 \pm 0,30^{\mathrm{b}}$ & $1,98 \pm 0,50^{\mathrm{b}}$ \\
\hline \multirow{2}{*}{ Enhalus acoroides } & 20 & $0,91 \pm 0,52^{\mathrm{a}}$ & $3,00 \pm 0,62^{\mathrm{a}}$ \\
& 25 & $1,76 \pm 0,64^{\mathrm{ab}}$ & $3,50 \pm 0,50^{\mathrm{ab}}$ \\
& 30 & $2,50 \pm 0,50^{\mathrm{b}}$ & $4,00 \pm 0,66^{\mathrm{b}}$ \\
\hline
\end{tabular}

\section{Total Volatile Base Nitrogen (TVBN) Fillet Ikan Nila}

Hasil (TVBN) yang dilakukan untuk mengetahui jumlah basa nitrogen yang mudah menguap (volatil) pada fillet ikan nila dengan penambahan ekstrak lamun dan tanpa penambahan lamun (kontrol) dan dilakukan penyimpanan suhu dingin selama 12 hari.

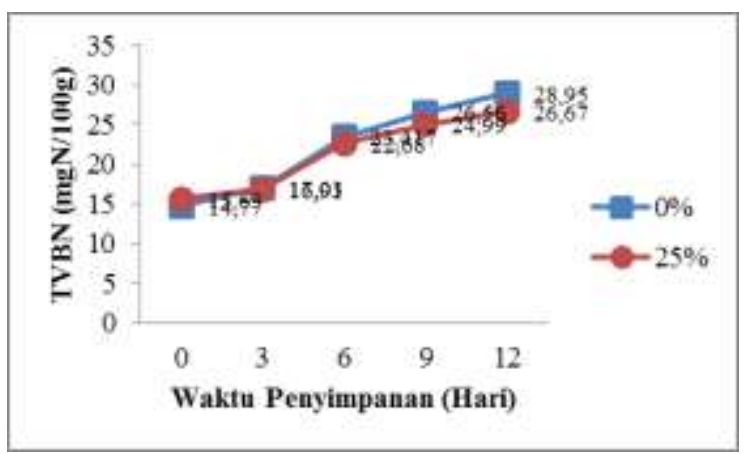

Gambar 1. Grafik Nilai TVBN Fillet Ikan Nila dengan Penambahan Ekstrak Lamun E. acoroides Berbeda Konsentrasi Selama Penyimpanan Dingin

(c) Copyright by Saintek Perikanan (Indonesian Journal of Fisheries Science and Technology), ISSN : 1858-4748
Hasil TVBN yang diperoleh di atas menunjukkan bahwa pada hari ke-12 penggunaan ekstrak Lamun $E$. acoroides $25 \%$ memiliki nilai TVBN yang lebih rendah dibandingkan dengan kontrol, hal ini terjadi karena ekstrak $E$. acoroides mengandung senyawa aktif yang dapat menghambat pertumbuhan bakteri pembusuk sehingga fillet ikan nila dengan penambahan ekstrak E. acoroides memiliki kesegaran lebih lama. Menurut Waryani et al. (2014) nilai TVBN semakin meningkat seiring bertambahnya waktu penyimpanan. Hal ini dikarenakanTVBN merupakan senyawa hasil degradasi protein karena aktivitas bakteri pembusuk. Peningkatan konsentrasi TVBN berhubungan dengan pertumbuhan mikroba dan dapat digunakan sebagai indikator kerusakan ikan. Banyaknya jumlah mikroba pada ikan menjadikan proses degradasi protein menjadi senyawa basa nitrogen lebih cepat sehingga konsentrasi TVBN juga meningkat tajam. Menurut Liviawaty dan Afrianto (2010) konsentrasi TVB akan meningkat seiring dengan bertambahnya lama penyimpanan, kadar TVB akan meningkat dengan menurunnya kesegaran ikan. Hal ini diperkuat oleh Husni et al. (2014) peningkatan kandungan TVB-N pada daging ikan selama penyimpanan disebabkan karena adanya degradasi protein dan derivatnya oleh 
mikroorganisme yang menghasilkan basa mudah menguap seperti Trimethylamine (TMA), amoniak, dan $\mathrm{H}_{2} \mathrm{~S}$.

Konsentrasi ekstrak E. acoroides dan lama penyimpanan memiliki pengaruh terhadap nilai TVBN pada fillet ikan nila. Semakin lama waktu penyimpanan akan meningkatkan nilai TVBN, namu dengan penambahan ekstrak E. acoroides $25 \%$ dapat mengurangi penginkatan TVBN fillet ikan nila dibanding kontrol. Menurut Susanto et al. (2011) bahwa peningkatan nilai TVB-N tercepat terjadi pada kontrol, sedangkan yang terlambat pada ikan kembung dengan perlakuan penambahan bahan alami.

\section{Total Plate Count (TPC) Fillet Ikan Nila}

Hasil uji (TPC) yang dilakukan untuk mengetahui jumlah peningkatan bakteri pada fillet ikan nila dengan penambahan ekstrak E. acoroides dan tanpa penmbahan ekstrak (kontrol) dan dilakukan penyimpanan suhu dingin selama 12 hari. Nilai logaritma (TPC) disajikan dalam Gambar 2.

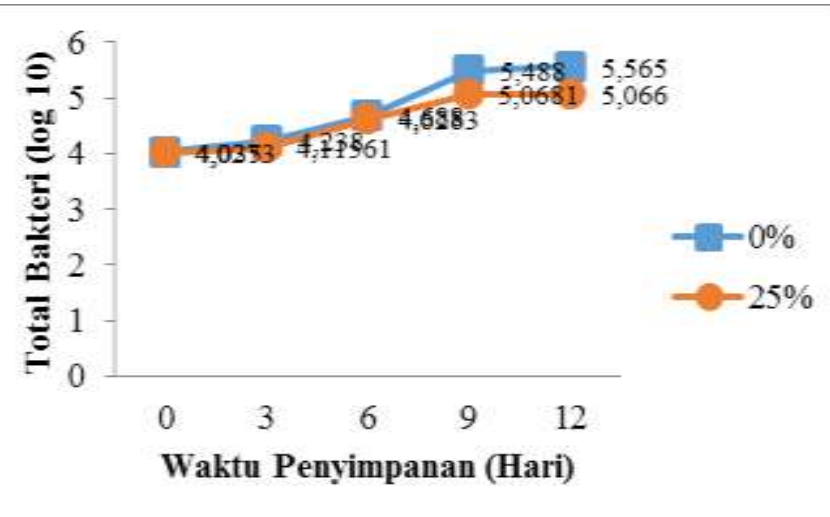

Gambar 2. Grafik Nilai TPC Fillet Ikan Nila dengan Penambahan Ekstrak Lamun E. acoroides Berbeda Konsentrasi Selama Penyimpanan Dingin

Grafik nilai TPC, pada grafik tersebut terlihat bahwa nilai TPC yang diperoleh pada hari ke-12 pada konsentrasi $0 \%$ lebih tinggi dibanding nilai TPC pada konsentrasi $25 \%$. Hal tersebut menunjukkan bahwa penggunaan ekstrak E. acoroides yang digunakan sebagai antibakteri pada fillet ikan nila cukup efektif untuk menghambat pertumbuhan bakteri selama penyimpanan dingin. Menurut Wicaksono (2010) dalam Husni et al. (2014) menunjukkan bahwa fillet nila merah yang disimpan pada suhu dingin dengan perlakuan ekstrak Sargassum sp. 1\% masih layak dikonsumsi sampai hari ke-12 berdasarkan total kandungan bakterinya.

Efektivitas ekstrak Lamun $E$. acoroides dapat menghambat pertumbuhan bakteri, karena mengandung senyawa bioaktif yang memiliki kemampuan untuk menghambat pertumbuhan bakteri, seperti senyawa flavonoid, alkaloid, dan triterpenoid yang mampu mengganggu membran sel bakteri. Hal ini diperkuat oleh Darwis (2001), menyatakan bahwa alkaloid adalah golongan senyawa basa bernitrogen yang kebanyakan heterosiklik yang banyak terdapat pada tumbuhan, termasuk lamun.

\section{pH (Derajat Keasaman)}

Hasil $\mathrm{pH}$ yang dilakukan untuk mengetahui tingkat keasaman pada fillet ikan nila dengan penambahan ekstrak lamun dan tanpa penambahan lamun (kontrol) dan dilakukan penyimpanan suhu dingin selama 12 hari.

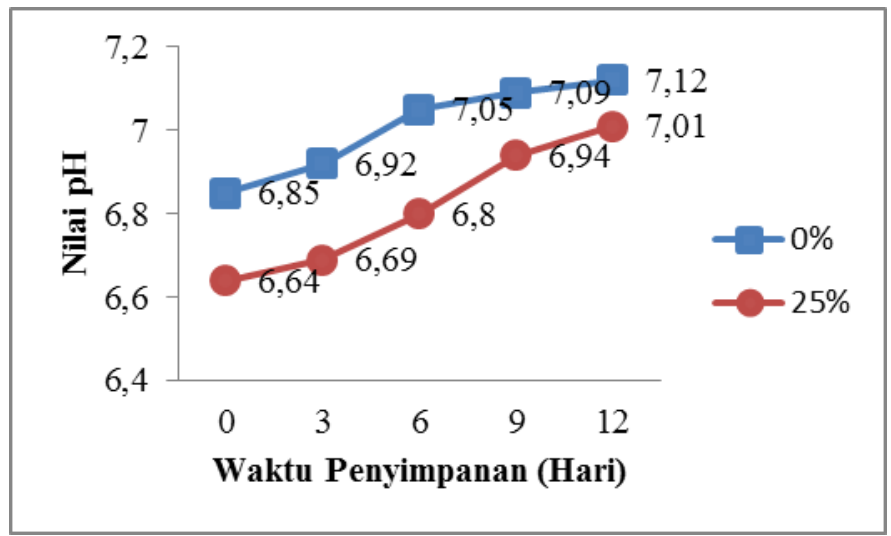

Gambar 3. Grafik Nilai pH Fillet Ikan Nila dengan Penambahan Ekstrak Lamun E. acoroides Berbeda Konsentrasi Selama Penyimpanan Dingin

Berdasarkan hasil uji pH pada masing-masing perlakuan, menunjukan bahwa nilai $\mathrm{pH}$ fillet ikan nila dengan penambahan lamun lebih rendah dibandingkan dengan kontrol. Namun masih dapat dikatakan dalam $\mathrm{pH}$ yang netral. Menurut Hadiwiyoto (1993), ikan segar mempunyai pH sekitar 6,8 hingga 7. Selama pendinginan dan pembekuan $\mathrm{pH}$ daging ikan akan berubah. Nilai $\mathrm{pH}$ daging ikan akan turun dari sekitar 7 menjadi 6,3 kemudian naik lagi selama penyimpanan suhu rendah. Perubahan ini terjadi dalam dua tahap. Tahap awal pendinginan atau pembekuan, $\mathrm{pH}$ daging ikan akan turun kemudian selanjutnya $\mathrm{pH}$ akan naik lagi. Terjadinya penurunan dan kenaikan $\mathrm{pH}$ ini banyak dikaitkan dengan keadaan fisiologik daging ikan, komposisi senyawa-senyawa garam yang ada pada daging ikan, dan aktivitas enzim. Daging ikan dalam keadaan pre rigor akan mengalami penurunan $\mathrm{pH}$ lebih banyak pada waktu didinginkan atau dibekukan karena proses glikolisis anaerobik yang menyebabkan terbentuknya asam laktat masih berlangsung. Kenaikan pH mungkin juga disebabkan karena berkembangnya bakteri psikrofil yang dapat menyebabkan terbentuknya basa-basa volatil makin banyak. Lamanya pendinginan atau pembekuan dan rendahnya suhu juga mempunyai peranan penting pada perubahan $\mathrm{pH}$ daging ikan. $\mathrm{pH}$ daging ikan akan menurun secara lambat dengan makin rendahnya suhu penyimpanan.

\section{KESIMPULAN}

Berdasarkan hasil penelitian maka dapat diambil kesimpulan bahwa Lamun E. acoroides, C. rotundata, dan T. hemprichii masing-masing mengandung senyawa bioaktif yang dapat dijadikan sebagai antibakteri yaitu alkaloid, flavonoid, dan triterpenoid. Ekstrak E. acoroides 25\% terbukti mampu menambah masa simpan fillet ikan nila berdasarkan nilai TVBN, TPC dan $\mathrm{pH}$ sampai pada hari ke-12 selama penyimpanan dingin. 


\section{UCAPAN TERIMA KASIH}

Pada kesempatan ini kami mengucapkan terimakasih kepada DITLITABMAS DITJEN DIKTI Kementrian Pendidikan dan Kebudayaan Republik Indonesia yang telah membiayai penelitian ini.

\section{DAFTAR PUSTAKA}

Astuti, I. 2014. Pemanfaatan Ekstrak Daun Belimbing Wuluh untuk Menghambat Peningkatan Histamin dan Penurunan Mutu Ikan Cakalang (Katsuwonus pelamis L). [Tesis]. Program Pascasarjana. Universitas Hasanudin. Makassar.

Badan Standarisasi Nasional (BSN). 2006. Cara Uji Organoleptik Ikan Segar No. SNI 2346.2006. Badan Standarisasi Nasional. Jakarta Darwis S.A. dan Achmad B. 2001. Kimia Organik Bahan Alam Laut. Universitas Terbuka. Jakarta

Badan Standarisasi Nasional (BSN). 2006. Cara Uji Mikrobiologi Bagian 3: Penentuan Angka Lempeng Total (ALT) pada Produk Perikanan No. SNI 012332.3-2006. Badan Standarisasi Nasional. Jakarta.

Darwis S.A. dan Achmad B. 2001. Kimia Organik Bahan Alam Laut. Universitas Terbuka. Jakarta.

Dewi, C.S.U., Dedi S., dan Mujizat K.. 2012. Komponen Fitokimia Dan Toksisitas Senyawa Bioaktif Dari Lamun Enhalus Acoroides Dan Thalassia Hemprichii Dari Pulau Pramuka, Dki Jakarta. Jurnal Teknologi Perikanan dan Kelautan. 3(1): 23-28.
Hadiwiyoto, S. 1993. Teknologi Pengolahan Hasil Perikanan Jilid I: Teknik Pendinginan Ikan. CV. Paripurna, Jakarta.

Husni,A., Ustadi dan Hakim, A. 2014. Penggunaan Ekstrak Rumput Laut Padinasp. untuk Peningkatan Daya Simpan Filet Nila Merah yang Disimpan pada Suhu Dingin. Agritech, 34(3): 239-246.

Kordi, K.M.G. 2010. Budi Daya Ikan Nila di Kolam Terpal.Lily Publisher, Yogyakarta.

Kusriningrum, R. S. 2008. Perancangan Percobaan. Airlangga University Press. Surabaya.

Noer, R. dan Rosa D.. 2016. Uji Kualitatif Fitokimia Daun Ruta angustifolia. Faktor Exacta 9(3): 200-206.

Olopade, O. A., I.O. Taiwo, A.A. Lamidi and O.A. Awonaike. 2016. Proximate Composition of Nile Tilapia (Oreochromis niloticus) (Linnaeus, 1758) and Tilapia Hybrid (Red Tilapia) from Oyan Lake, Nigeria. UASVM Food Science and Technology., 73 (1).

Ravikumar, S., Thajuddin, N, P. Suganthi, S. Jacob Inbaneson and Vinodkumar, 2008. Bioactive Potential Of Seagrass Bacteria Against Human Bacterial Pathogens. Journal Of Environmental Biology, (31)387-389.

Rumagit, H.M., Max R.J.R., dan Sri S.. 2015. Uji Fitokimia dan Uji Aktivitas Antioksidan Dari Ekstrak Etanol Spons Lamellodysidea Herbacea. Jurnal Ilmiah Farmasi. 4(3): 183-192.

Susanto E., T. W. Agustini., F. Swastawati, T. Surti., A. S. Fahmi., M.F. Albar., dan M. K. Nafis. 2011. Pemanfaatan Bahan Alami untuk Memperpanjang Umur Simpan Ikan Kembung (Rastrelliger neglectus). Jurnal Perikanan (J. Fish. Sci), 8 (2): 60 69. 